\title{
Pengaruh Motivasi Belajar Taruna Dan Kompetensi Dosen Terhadap Prestasi Belajar Taruna di Politeknik Penerbangan Surabaya
}

\author{
Sri Lestari \\ Bambang Wasito ${ }^{1}$ \\ Politeknik Penerbangan Surabaya \\ Jl. Jemur Andayani 1/73 Wonocolo Surabaya 60236 \\ Telp.(031)841087, Fax.(031)8490005 \\ 1bamcito@gmail.com
}

\begin{abstract}
Motivation learn is the effort someone cadets to provide all energy condition to learn so that he will or wish process study. Lecturer play a part good enough important in the plan and also curriculum execution. Beside that lecturer is planner, curriculum developer and executor to its class, because lecturer also curriculum developer line which is terdepan hence lecturer also which always evaluate and completion to curriculum. From result of calculation with t test above it can be interpreted that cadet motivation /(XI), $t$ value obtained is 17,264 and its significance value is 0.000, this value is smaller than $\alpha=0,05$, Lecturer competence /(X2), t arithmetic value obtained is 14.255 and the significance value is 0,000 , this value is smaller than $\alpha=0,05$ meaning that cadet motivation (X1) and lecturer competence (X2) are partially significant to achievement learning cadets $(Y)$ atAviation Polytechnic of Surabaya. The result of $F$ Test calculation done with the help of SPSS program obtained F value counted 298,095. The significance value obtained is 0.000, the value of significance is smaller than the value of $\alpha$ that is 0.05 , meaning that cadet motivation (X1) and lecturer competence $(X 2)$ together significantly affect achievement learning cadets $(Y)$ atAviation Polytechnic of Surabaya. The result of SPSS practice on standardized regression coefficient ( $\beta$ ) or Standardized of Coefficients Beta, it is known that variable X2 that is cadet motivation has standardized coefficient of standard ( $\beta$ ) or Standardized of Coefficients Beta is 2,542 compare with other independent variable variable X2 that is taruna motivation is independent va riable that dominant influence dependent variable that isachievement learning cadets $(Y)$ atAviation Polytechnic of Surabaya.
\end{abstract}

Key Words :Motivation, lecturer competence, achievement learning cadets

\section{Pendahuluan}

\subsection{Latar Belakang Masalah}

Sebagai organisasi publik, Politeknik Penerbangan Surabaya di tuntut mampu memberikan pelayanan kepada masyarakat yang lebih baik, sehingga dapat berperan serta dalam agenda Road Map to Zero Accident melalui kegiatannya mencetak sumber daya manusia penerbangan yang memiliki kompetensi dan daya saing tinggi.Politeknik Surabaya mempunyai visi yaitu terwujudnya peserta didik menjadi masyarakat penerbangan yang handal, berdaya saing dan memberikan nilai tambah. Adapun misi dari Politeknik Penerbangan Surabaya yang pertamaadalah menyiapkan peserta didik menjadi anggota masyarakat penerbangan yang memiliki kemampuan professional di bidang teknik dan keselamatan penerbangan melalui pelaksanaan diklat baik full class, sharing dan special course program. Kedua melaksanakan diklat dengan penekanan pada penerapan keahlian serta pembentukan kompetensi untuk dapat menangani pekerjaan menurut praktek-praktek yang berlaku secara umum di bidang teknik dan keselamatan penerbangan. Ketiga melaksanakan penelitian yang bertujuan untuk mengembangkan pengetahuan, pengalaman dan daya nalar untuk berperan serta dalam memecahkan masalah dunia penerbangan. Keempat melaksanakan pengabdian kepada masyarakat yang bertujuan menjalin 
hubungan dengan dunia penerbangan dan masyarakat melalui kerja sama yang saling menguntungkan.Salah satu usaha yang digunakan untuk meningkatkan visi dan misi tersebut adalah meningkatkan prestasi belajar taruna yang ada di Politeknik Surabaya.

Dosen memegang peranan penting yang cukup baik dalam perencanaan maupun pelaksanaan kurikulum. Disamping itu dosen adalah perencana, pelaksana dan pengembang kurikulum bagi kelasnya, karena dosen juga barisan pengembang kurikulum yang terdepan maka dosen pulalah yang selalu melakukan evaluasi dan penyempurnaan terhadap kurikulum. Bertitik tolak dari upaya untuk menumbuhkan motivasi guna mencapai prestasi belajar yang diharapkan, maka penulis tertarik untukmengambil judul dalam penelitian ini sebagai berikut : Pengaruh Motivasi Belajar Taruna dan KompetensiDosen terhadap Prestasi Belajar Taruna diPoliteknik Penerbangan Surabaya.

\subsection{Rumusan Masalah}

Setelah diuraikan latar belakang masalah diatas, kemudian disusun rumusan masalah dalam penelitian. Adapun rumusan masalah dalam penelitian ini adalah :

1. Apakah motivasi belajar taruna dan kompetensi dosen berpengaruh secara parsial terhadap prestasi belajar taruna lalu lintas udara di Politeknik Penerbangan Surabaya?

2. Apakah motivasi belajar taruna dan kompetensi dosen berpengaruh secara simultanterhadap prestasi belajar taruna lalu lintas udara di Politekniik Penerbangan Surabaya?

3. Manakah dari motivasi belajar taruna dan kompetensi dosen yang memiliki pengaruh dominanterhadap prestasi belajar taruna lalu lintas udara di Politeknik Penerbangan Surabaya?

\subsection{Kerangka Konseptual.}

Dari beberapa teori tentang kwalitas dosen, pengalaman dosen, motivasi dan beberapa penelitian terdahulu yang mendukung penelitian ini, maka untuk lebih jelasnya penulis membuat kerangka konseptual Adapun kerangka konsep penelitian sebagai berikut :

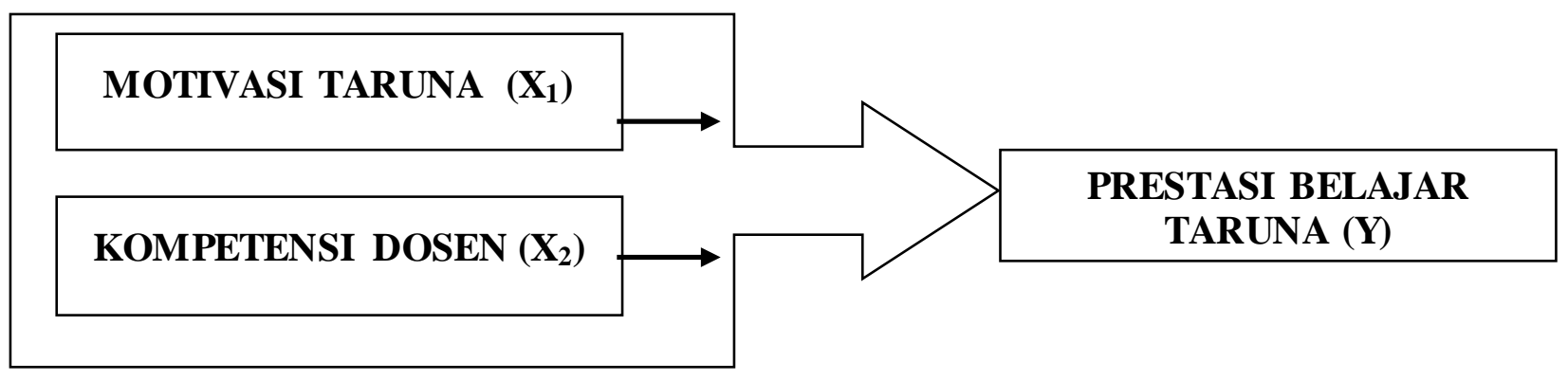

\subsection{Hipotesis Penelitian}

\section{Gambar 1. Kerangka Konseptual}

Hioptesis adalah dugaan sementara penelitian yang kebenarannya perlu diuji secara empiris. Berdasarkan model tersebut, maka hipotesis penelitian yang dirumuskan dan diuji kebenarannya melalui penelitian ini adalah :

1. Motivasi belajar taruna dan kompetensi dosen berpengaruh secara parsial terhadap prestasi belajar taruna lalu lintas udara di Politeknik Penerbangan Surabaya.

2. Motivasi belajar taruna dan kompetensi dosen berpengaruh secara simultan terhadap prestasi belajar taruna lalu lintas udara di PoliteknikPenerbangan Surabaya.

3. Motivasi belajar taruna memiliki pengaruh dominanterhadap prestasi belajar taruna lalu 
lintas udara di Politeknik Penerbangan Surabaya.

\section{Metode Penelitian}

\subsection{Jenis Penelitian.}

Penelitian ini termasuk dalam kategori penelitian Explanatif(penelitian penjelasan) yaitu penelitian yang berusaha menjelaskan hubungan kausal dan menguji keterkaitan yang terjadi antara fakta-fakta dan pengembangan sumber daya manusia terhadap kinerja karyawan.Arik unto (2008: 67), mengemukakan bahwa penelitian survey adalah penelitian yang dilakukan pada populasi besar maupun kecil, tetapi data yang dipelajari adalah data dari sampel yang diambil dari populasi tersebut, sehingga ditemukan kejadian-kejadian relatif, distribusi dan hubunganhubungan anatara variabel sosiologis maupun psikologis. Berdasarkan pendapat kedua ahli tersebut maka penelitian ini adalah explanatif survey dengan memperlakukan data melalui informasi primer tentang data yang berhubungan dengan variabel penelitian dikumpulkan dari responden dengan menggunakan kuisioner

\subsection{Populasi dan Sampel Penelitian}

\section{Populasi}

Menurut Singarimbun $(2009 ; 108)$ juga menyatakan bahwa populasi atau universe adalah jumlah keseluruhan dan unit analisa yang ciri-cirinya akan diduga. Arikunto (2008) menyatakan bahwa populasi adalah keseluruhan obyek penelitian. Berkaitan dengan pengertian diatas, maka yang menjadi populasi dalam penelitian ini adalah seluruh Taruna Diploma III Lalu Lintas Udara sebagairesponden sebanyak 50 responden.

\section{Sampel Penelitian}

Menurut Singarimbun (2009), sampel sebagai bagian atau wakil populasi yang memiliki ciriciri: dapat mencerminkan seluruh populasi, dapat menentukan presisi (ketepatan) dari hasil penelitian. Arikunto (2008) menyatakan bahwa sampel adalah sebagian atau wakil populasi yang diteliti. Adapun sampel dalam penelitian ini adalah sebanyak populasi yang ada yaitu 50 responden dan merupakan penelitian sensus(Total Sampling ).

\subsection{Definisi Operasional Variabel Penelitian}

Adapun Definisi Operasional Variabel Penelitianadalah sebagai berikut :

\section{Variabel Motivasi Taruna (X1)}

Adalah dorongan yang dimiliki taruna yang bersumber dari dalam dirinya sendiri yang didasarkan pada keinginan dan kebutuhan untuk mencapai tujuan belajar juga dorongan yang ditimbulkan oleh kondisi pembelajaran yang diciptakan oleh dosen.

2. Variabel bebas Kompetensi Dosen(X2)

Adalah kemampuan dosen dalam mengemban tugasnya pada hal-hal yang berkaitan dengan pelaksanaan proses pendidikan dan pembelajaran dikampus.

3. Variabel terikat atau variabel dependen (Y)

Yaitu hasil belajar taruna setelah mengalami proses pengajaran di Akademi. Data tentang hasil taruna berupa data hasil UAS.

\subsection{Teknik Pengumpulan Data}

Sedangkan proses pengumpulan data dalam penelitian ini dibagi menjadi dua yaitu:

1. Pengumpulan Data Primer :

a. Observasi dimana peneliti melakukan pengamatan langsung kelapangan 
b. Kuisioner yaitu dengan menyampaikan naskah pertanyaan untuk diisi oleh responden.

2. Pengumpulan Data Sekunder dengan cara mengadakan evaluasi dengan cara mengadakan evaluasi terhadap laporan hasil pemeriksaan.

\section{Hasil Penelitian}

\subsection{Pengujian Validitas}

Adapun kriteria suatu butir / pertanyaan adalah valid jika terdapat korelasi yang signifik an yang ditunjukkan dengan nilai signifikansi yang kurang dari nilai $\alpha=0,05$ antara butir pertanyaan yang diukur validitasnya dengan skor total butir pertanyaan.

\subsection{Pengujian Reliabilitas}

Pada hasil uji reliabilitas dengan uji statistik Cronbach Alpha diketahui bahwa variabel dikatakan reliabel jika memberikan nilai cronbach alpha >0,6 (Nunnally, 1969).

\section{Tabel 2}

Nilai Cronbach's Alpha variabel Motivasi Taruna (X1)

\section{Reliability Statistics}

\begin{tabular}{|c|r|}
\hline $\begin{array}{c}\text { Cronbach's } \\
\text { Alpha }\end{array}$ & Nof ltems \\
\hline .973 & 9 \\
\hline
\end{tabular}

Sumber : Hasil Olah SPSS

Tabel 3

Nilai Cronbach's Alpha variabel Kompetensi Dosen (X2)

\section{Reliability Statistics}

\begin{tabular}{|c|r|}
\hline $\begin{array}{c}\text { Cronbach's } \\
\text { Alpha }\end{array}$ & Nof ltems \\
\hline .958 & 6 \\
\hline
\end{tabular}

Sumber : Hasil Olah SPSS

Dari hasil perhitungan pada lampiran SPSS dapat diketahui bahwa nilai Cronbach's Alpha diatas 0,6 maka dapat dikatakan bahwa kusioner pada penelitian ini adalah reliabel.

\subsection{Persamaan regresi linier berganda}

Persamaan regresi linier berganda mengukur hubungan dari masing-masing variabel bebas terhadap variabel terikatnya. Berdasarkan hasil pengolahan SPSS yang disajikan pada lampiran maka diperoleh hasil sebagai berikut : 
Tabel 4

Nilai Koefisien Regresi

Coefficients $\mathrm{s}^{\mathrm{a}}$

\begin{tabular}{|c|c|c|c|c|c|c|c|c|c|c|c|}
\hline \multirow{2}{*}{\multicolumn{2}{|c|}{ Model }} & \multicolumn{2}{|c|}{$\begin{array}{c}\text { Unstandardized } \\
\text { Coefficients }\end{array}$} & \multirow{2}{*}{$\begin{array}{c}\text { Standardized } \\
\text { Coefficients }\end{array}$} & \multirow[b]{2}{*}{$t$} & \multirow[b]{2}{*}{ Sig. } & \multicolumn{3}{|c|}{ Correlations } & \multicolumn{2}{|c|}{ Collinearity Statistics } \\
\hline & & B & Std. Error & & & & Zero-order & Partial & Part & Tolerance & VIF \\
\hline \multirow[t]{3}{*}{1} & (Constant) & 67.890 & .922 & & 67.378 & .000 & & & & & \\
\hline & $\mathrm{X} 1$ & 17.276 & 2.048 & 2.758 & 17.264 & .000 & .892 & .796 & .710 & .973 & 1.587 \\
\hline & $\mathrm{X} 2$ & 14.912 & 2.098 & 2.542 & 14.255 & .000 & .893 & .797 & .712 & .987 & 1.699 \\
\hline
\end{tabular}

a. Dependent Variable: $Y$

Sumber : Hasil Olah SPSS

Pada hasil pengolahan SPSS yang terdapat dalam lampiran, maka dapat dibuat persamaan regresi linier berganda sebagai berikut :

$\mathrm{Y}=67,890+17,276 \mathrm{X}_{1}+14,912 \mathrm{X}_{2}$

Dari hasil persamaan tersebut diatas, maka dapat diartikan bahwa :

1. Nilai konstanta adalah sebesar 67.890, Hal ini menyatakan bahwa tanpa adanya pengaruh variabel bebas yaitu motivasi taruna(X1) dan kompetensi dosen (X2) maka prestasi belajar taruna (Y) di PoliteknikPenerbangan Surabaya konstan sebesar 67,890.

2. Nilai koefisien regresi dari variabel bebas motivasi taruna(X1) adalah 17,276. Nilai koefisien tersebut mengandung arti jika nilai variabel bebas yaitu motivasi taruna(X1) ditingkatkan sebesar satu satuan maka akan menyebabkan peningkatan nilai dari variabel terikat yaituprestasi belajar taruna (Y) di Politeknik Penerbangan Surabaya sebesar 17,276 satuan. Dengan asumsi bahwa nilai dari variabel bebas yang lain adalah konstan atau nol.

3. Nilai koefisien regresi dari variabel bebas kompetensidosen (X2) adalah 14,912. Nilai koefisien tersebut mengandung arti jika nilai variabel bebas yaitu kompetensidosen (X2) ditingkatkan sebesar satu satuan maka akan menyebabkan peningkatan nilai dari variabel terikat yaituprestasi belajar taruna (Y) di Politeknik Penerbangan Surabaya sebesar 14,912 satuan. Dengan asumsi bahwa nilai dari variabel bebas yang lain adalah konstan atau nol.

\subsection{Uji Asumsi Klasik}

\section{Uji Normalitas}

Hasil pengolahan SPSS yang menunjukkan grafis dari Normal Probabiliy Plot adalah sebagai berikut : 


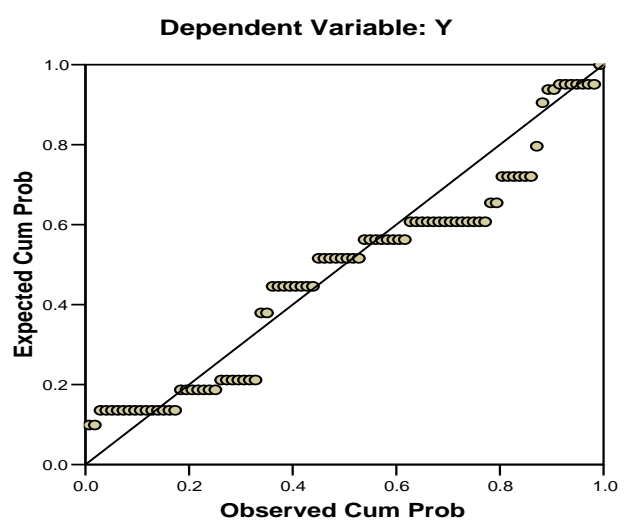

Gambar 2

Normal Probability Plot

Sumber :Hasil OlahSPSS

\section{Uji Multikolinieritas}

Multikolinieritas dilihat dari nilai tolerance dan nilai VIF yang diperolehnya. Jika nilai tolerance yang diperoleh kurang dari 1 dan VIF antara 1 dan 10 maka dapat dikatakan bahwa persamaan suatu model penelitian tidak menunjukkan gejala multikolinieritas. Selain itu Nilai tolerance dan VIF yang diperoleh untuk model penelitian ini adalah sebagai berikut :

\section{Tabel 5}

\section{Collinearity Statistic}

Coefficients

\begin{tabular}{|c|c|c|c|c|c|c|c|c|c|c|c|}
\hline \multirow{2}{*}{\multicolumn{2}{|c|}{ Model }} & \multicolumn{2}{|c|}{$\begin{array}{l}\text { Unstandardized } \\
\text { Coefficients }\end{array}$} & \multirow{2}{*}{$\begin{array}{c}\text { Standardized } \\
\text { Coefficients } \\
\text { Beta } \\
\end{array}$} & \multirow[b]{2}{*}{$t$} & \multirow[b]{2}{*}{ Sig. } & \multicolumn{3}{|c|}{ Correlations } & \multicolumn{2}{|c|}{ Collinearity Statistics } \\
\hline & & B & Std. Error & & & & Zero-order & Partial & Part & Tolerance & VIF \\
\hline \multirow[t]{3}{*}{1} & (Constant) & 67.890 & .922 & & 67.378 & .000 & & & & & \\
\hline & $\mathrm{X} 1$ & 17.276 & 2.048 & 2.758 & 17.264 & .000 & .892 & .796 & .710 & .973 & 1.587 \\
\hline & X2 & 14.912 & 2.098 & 2.542 & 14.255 & .000 & .893 & .797 & .712 & .987 & 1.699 \\
\hline
\end{tabular}

a. Dependent Variable: $Y$

\section{Uji Heteroskedastisitas}

\section{Sumber :Hasil Olah SPSS.}

Model yang baik adalah yang homoskedastisitas atau tidak terjadi heteroskedastisitas. Hasil perhitungan korelasi rank spearman SPSS untuk model persamaan regresi pada penelitian ini adalah sebagai berikut : 
Tabel 6

Hasil Korelasi Rank Spearman

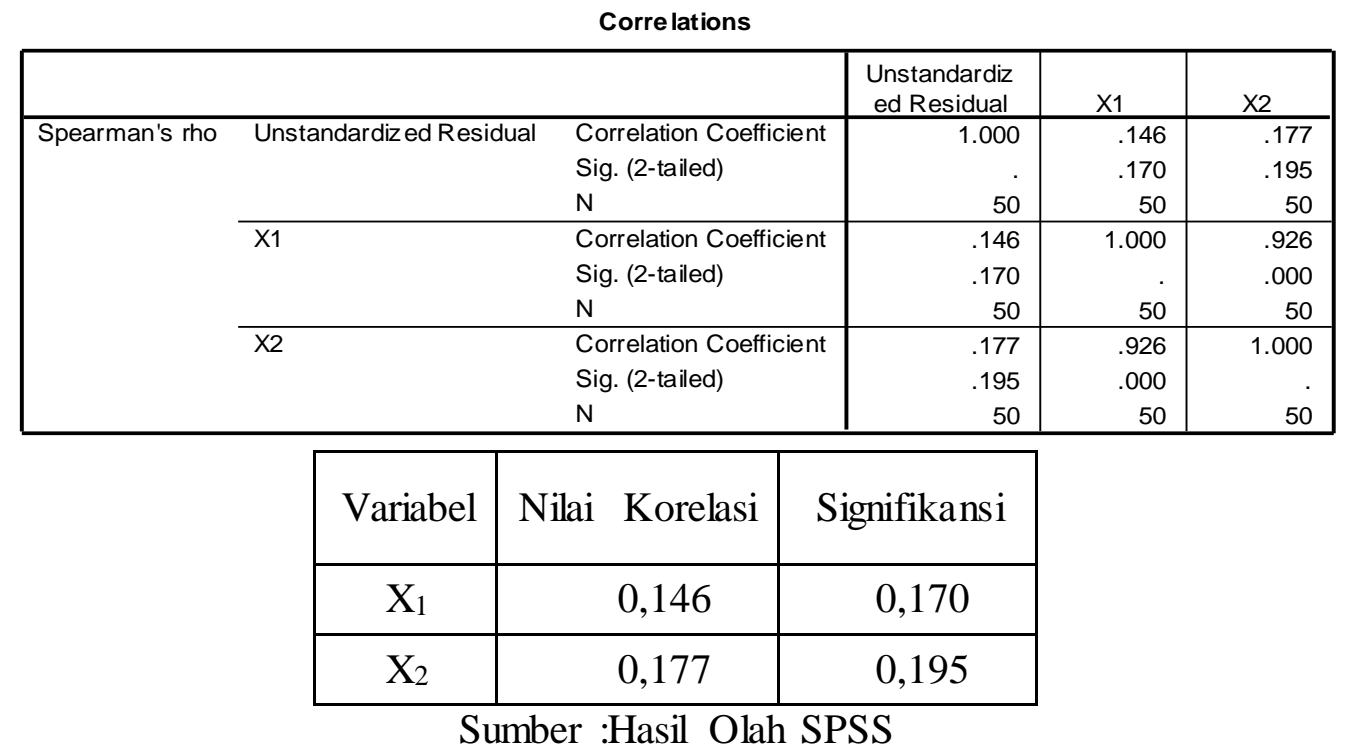

\section{Autokorelasi.}

Pada pengujian autokorelasi bertujuan menguji apakah dalam sebuah model regresi linier ada korelasi antara kesalahan pengganggu pada periode $\mathrm{t}$ dengan kesalahan pada periode t-1 (sebelumnya). Jika terjadi korelasi maka dinamakan ada problem autokorelasi.

Nilai Durbin-Watson pada olahan SPSS sebagai berikut :

\section{Tabel 7}

Hasil nilai Durbin-Watson

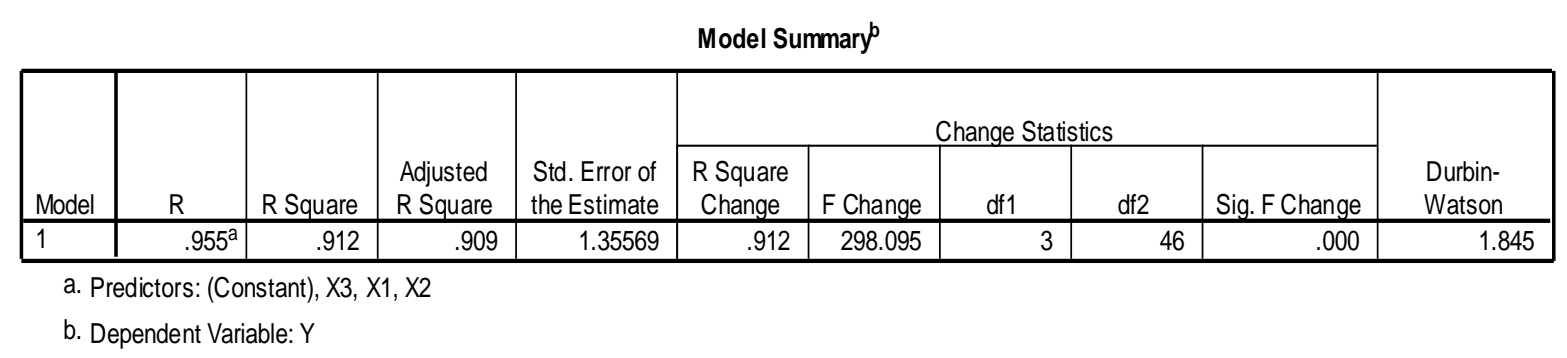

Sumber :Hasil Olah SPSS

Dari hasil pengujian SPSS diketahui bahwa nilai DW sebesar 1,845 Nilai ini berada pada Nilai DW antara 1,55 s.d 2,46; artinya data yang ada tidak ada autokorelasi.

\subsection{Koefisien korelasi $(R)$ dan determinasi simultan $\left(R^{2}\right)$}

Hasil perhitungan SPSS mengenai koefisien korelasi dan determinasi ditunjukkan oleh tabel berikut ini : 
Tabel 8

Koefisien korelasi dan determinasi simultan

Model Summary ${ }^{p}$

\begin{tabular}{|c|c|c|c|c|c|c|c|c|c|c|}
\hline \multirow[b]{2}{*}{ Model } & \multirow[b]{2}{*}{$\mathrm{R}$} & \multirow[b]{2}{*}{ R Square } & \multirow[b]{2}{*}{$\begin{array}{l}\text { Adjusted } \\
\text { R Square }\end{array}$} & \multirow[b]{2}{*}{$\begin{array}{l}\text { Std. Error of } \\
\text { the Estimate }\end{array}$} & \multicolumn{5}{|c|}{ Change Statistics } & \multirow[b]{2}{*}{$\begin{array}{l}\text { Durbin- } \\
\text { Watson }\end{array}$} \\
\hline & & & & & $\begin{array}{l}\text { R Square } \\
\text { Change }\end{array}$ & F Change & $\mathrm{df} 1$ & $\mathrm{df} 2$ & Sig. F Change & \\
\hline 1 & $.955^{\mathrm{a}}$ & .912 & .909 & 1.35569 & .912 & 298.095 & 3 & 46 & .000 & 1.845 \\
\hline
\end{tabular}

a. Predictors: (Constant), X3, X1, X2

b. Dependent Variable: $Y$

\section{Sumber : Hasil Olah SPSS}

Pada tabel tersebut diketahui bahwa nilai koefisien korelasi (R) adalah 0,995 atau mendekati 1. Artinya hubungan antara variabel bebas yang meliputi motivasi taruna (X1) dan kompetensi dosen (X2) dengan variabel terikat yaitu prestasi belajar taruna (Y) di Politeknik Penerbangan Surabaya kuat searah erat.

Prosentase pengaruh variabel bebas terhadap variabel terikat yang ditunjukkan oleh koefisien determinasi simultan ( $\mathrm{R}_{\text {squared}}$ ) adalah sebesar 0,912 atau 91,2\%. Hal ini berarti bahwa naik turunnya variabel terikat yaitu prestasi belajar taruna (Y) di Politeknik Penerbangan Surabaya dipengaruhi oleh bebas yang meliputi variabel motivasi taruna (X1) dan kompetensi dosen (X2) sebesar $91,2 \%$ dan sisanya sebesar 8,8\% dipengaruhi oleh variabel lain di luar penelitian ini.

\subsection{Uji t (uji parsial)}

Uji t dipergunakan untuk mengukur tingkat pengaruh secara parsial dari variabel bebas yang meliputi variabel motivasi taruna (X1) dan kompetensi dosen (X2) terhadap variabel terikat yaitu prestasi belajar taruna (Y) di Politeknik Penerbangan Surabaya.

Tabel 9

Nilai thitung dan signifikansi

Coefficients $^{\mathrm{a}}$

\begin{tabular}{|c|c|c|c|c|c|c|c|c|c|c|c|}
\hline \multirow[b]{2}{*}{ Mode } & & \multicolumn{2}{|c|}{$\begin{array}{c}\text { Unstandardized } \\
\text { Coefficients }\end{array}$} & \multirow{2}{*}{$\begin{array}{c}\begin{array}{c}\text { Standardized } \\
\text { Coefficients }\end{array} \\
\text { Beta }\end{array}$} & \multirow[b]{2}{*}{$t$} & \multirow[b]{2}{*}{ Sig. } & \multicolumn{3}{|c|}{ Correlations } & \multicolumn{2}{|c|}{ Collinearity Statistics } \\
\hline & & $B$ & Std. Error & & & & Zero-order & Partial & Part & Tolerance & VIF \\
\hline \multirow[t]{3}{*}{1} & (Constant) & 67.890 & .922 & & 67.378 & .000 & & & & & \\
\hline & $\mathrm{X} 1$ & 17.276 & 2.048 & 2.758 & 17.264 & .000 & .892 & .796 & .710 & .973 & 1.587 \\
\hline & X2 & 14.912 & 2.098 & 2.542 & 14.255 & .000 & .893 & .797 & .712 & .987 & 1.699 \\
\hline
\end{tabular}

a. Dependent Variable: $Y$

Sumber : Hasil Olah SPSS

Dari hasil perhitungan dengan uji t diatas maka dapat di interprestasikan sebagai berikut :

1. Untuk variabel motivasi taruna / (X1), nilai t hitung yang diperoleh adalah sebesar 17,264 dan nilai signifikansinya adalah 0,000 , nilai ini lebih kecil daripada $\alpha=0,05$, sehingga Ho ditolak dan Ha diterima yang berarti bahwa variabel motivasi taruna (X1) secara parsial memiliki pengaruh signifikan terhadap variabel terikat prestasi belajar taruna (Y) di Politeknik Penerbangan Surabaya.

2. Untuk variabel kompetensidosen / (X2), nilai thitung yang diperoleh adalah sebesar 14,255 dan nilai signifikansinya adalah 0,000 , nilai ini lebih kecil daripada $\alpha=0,05$, sehingga Ho 
ditolak dan Ha diterima yang berarti bahwa variabel kompetensidosen (X2) secara parsial memiliki pengaruh signifikan terhadap variabel terikat prestasi belajar taruna $(\mathrm{Y})$ di Politeknik Penerbangan Surabaya.

\subsection{Uji F (uji bersama / simultan)}

Nilai F hitung disajikan pada tabel di bawah ini :

Tabel 4.10

Nilai F Hitung dan signifikansi

ANOVA

\begin{tabular}{|ll|r|r|r|r|r|}
\hline Model & & \multicolumn{1}{c|}{$\begin{array}{c}\text { Sum of } \\
\text { Squares }\end{array}$} & df & Mean Square & F & Sig. \\
\hline 1 & Regression & 1643.598 & 3 & 547.866 & 298.095 & $.000^{\mathrm{a}}$ \\
& Residual & 158.059 & 46 & 1.838 & & \\
& Total & 1801.657 & 49 & & & \\
\hline
\end{tabular}

a. Predictors: (Constant), X3, X1, X2

b. Dependent Variable: $Y$

Sumber :Hasil OlahSPSS.

\subsection{Rangking Koefisien Regresi yang Distandarkan ( $\beta$ )}

Dari hasil perhitungan SPSS yang penulis lakukan mengenai koefisien regresi yang distandarkan $(\beta)$ atau Standardized of Coefficients Beta dapat ditunjukkan pada tabel berikut :

Tabel 4.11

Koefisien regresi yang distandarkan ( $\beta$ ) atau Standardized of Coefficients Beta

\begin{tabular}{|c|c|c|c|c|c|c|c|c|c|c|c|}
\hline \multicolumn{12}{|c|}{ Coefficients } \\
\hline \multirow[b]{2}{*}{ Model } & & \multicolumn{2}{|c|}{$\begin{array}{l}\text { Unstandardized } \\
\text { Coefficients }\end{array}$} & \multirow{2}{*}{$\begin{array}{c}\begin{array}{c}\text { Standardized } \\
\text { Coefficients }\end{array} \\
\text { Beta }\end{array}$} & \multirow[b]{2}{*}{$t$} & \multirow[b]{2}{*}{ Sig. } & \multicolumn{3}{|c|}{ Correlations } & \multicolumn{2}{|c|}{ Collinearity Statistics } \\
\hline & & $B$ & Std. Error & & & & Zero-order & Partial & Part & Tolerance & VIF \\
\hline 1 & (Constant) & 67.890 & .922 & & 67.378 & .000 & & & & & \\
\hline & $\mathrm{X} 1$ & 17.276 & 2.048 & 2.758 & 17.264 & .000 & .892 & .796 & .710 & .973 & 1.587 \\
\hline & $X 2$ & 14.912 & 2.098 & 2.542 & 14.255 & .000 & .893 & .797 & .712 & .987 & 1.699 \\
\hline
\end{tabular}

a. Dependent Variable: $Y$

Sumber : Hasil Olah SPSS.

\section{Kesimpulan}

\subsection{Kesimpulan}

Dari hasil pengujian yang penulis lakukan, maka dapat disimpulkan sebagai berikut :

1. Dari hasil perhitungan dengan uji $t$ diatas maka dapat di interprestasikan sebagai berikut :

a. Untuk variabel motivasi taruna / (X1), nilai thitung yang diperoleh adalah sebesar 17,264 dan nilai signifikansinya adalah 0,000 , nilai ini lebih kecil daripada $\alpha=0,05$, sehingga Ho ditolak dan Ha diterima yang berarti bahwa variabel motivasi taruna (X1) secara parsial memiliki pengaruh signifikan terhadap variabel terikat prestasi belajar taruna (Y) di Politeknik Penerbangan Surabaya. 
b. Untuk variabel kompetensi dosen / (X2), nilai t hitung yang diperoleh adalah sebesar 14,255 dan nilai signifikansinya adalah 0,000 , nilai ini lebih kecil daripada $\alpha=0,05$, sehingga Ho ditolak dan Ha diterima yang berarti bahwa variabel kompetensi dosen (X2) secara parsial memiliki pengaruh signifikan terhadap variabel terikat prestasi belajar taruna (Y) di Politeknik Penerbangan Surabaya.

2. Hasil perhitungan Uji $\mathrm{F}$ yang dilakukan dengan bantuan program SPSS diperoleh nilai $\mathrm{F}$ hitung sebesar 298,095. Nilai signifikansi yang diperoleh adalah sebesar 0,000, nilai signifikansi ini lebih kecil daripada nilai $\alpha$ yaitu 0,05. Dengan demikian Ho ditolak dan Ha diterima, artinya variabel independen yaitu variabel motivasi taruna (X1) dan kompetensi dosen (X2) secara bersama berpengaruh nyata terhadap prestasi belajar taruna $(\mathrm{Y})$ di Politeknik Penerbangan Surabaya.

3. Hasil olah SPSS mengenai koefisien regresi yang distandarkan $(\beta)$ atau Standardized of Coefficients Beta, maka diketahui bahwa variabel X1 yaitu motivasi taruna memiliki nilai koefisien regresi yang distandarkan $(\beta)$ atau Standardized of Coefficients Beta tertinggi yaitu 2,542 dibandingkan dengan variabel bebas yang lain, maka variabel X1yaitu motivasi taruna merupakan variabel bebas yang dominan mempengaruhi variabel terikat yaitu prestasi belajar taruna (Y) di Politeknik Penerbangan Surabaya.

\section{DAFTAR PUSTAKA}

Algifari, 2007, Analisis Regresi, Teori, Kasus, dan Solusi, Edisi Pertama, BPFE UGM, Jogyakarta.

Arief, Mathias, 2015, Motivasi dan Kinerja, Cetakan Pertama, LSIUP, Jakarta.

Amstrong, 2008, Sistem Pengendalian Manageman, Cetakan Ketiga, Terjemahan, Erlangga, Jakarta.

Arikunto, Suharsimi. 2013. Prosedur Penelitian Suatu Pendekatan Praktis. Penerbit Rineka Cipta Jakarta.

Bagus, Ida Mantra,2010. Sampling, Naskah Lokakarya Metode Penelitian Survey, PPS Kependudukan UGM Yogyakarta.

Bernardin, H-jhon and Joyce F.A. Russel, 2013,Human Resources Management, An Experiental Approach, Mc Graw-Hill.Inc. New York.

Buchari, Zainun,2009. Manajemen dan Motivasi, Balai Aksara, Jakarta.

Dajan, Anton 2006. Pengantar Metode Statistik II.Penerbit LP3ES, Jakarta.

Davis, Kaith, 2012. Human Reletion at Work, Mc Graw Hill Book Co, Inc. Kogakhusa Co. Ltd, Tokyo.

Djarwanto PS dan Pangestu Subagyo, 2013.Statistik Induktif. Edisi IV BPFE. Yogyakarta.

Durbin, Robert,2008The world of Work, Englewood Cliff, Printice Hall, Inc, New Jersey.

Flippo, Edwin B.,2014. ManajemenPersonalia, Erlangga, Surabaya, 1984.

Gibson, Ivancevich, Dornely, 2012, Organisasi perilaku, Stuktur, Proses, Edisi ke - 5, cetakan ke - 5, Erlangga, Jakarta.

Sunyoto. 2015. Tesis Unibraw Malang.Faktor-faktor motivasi terhadap produktivitas karyawan perusahaan rokok di Kotamadya / Kabupaten Malang.

Handoko T, Hani, 2012. Manajemen Personalia dan Sumber Daya Manusia, BPFE, Yogyakarta. Harun Al Rasyid, 2014. Teknik Penarikan Sampel dan Penyusunan Skala (Bahan Kuliah). 
Kuna, Winaya, 2013. Manajemen Sumber Daya Manusia, Bali. Penerbit Fakultas Ekonomi Udayana Denpasar

Mangkunegoro, A. Prabu, 2010, Manajemen Sumber daya Manusia Perusahaan, remaja Rosdakarya, Bandung.

Manullang, 2012, Manajemen Sumber Daya Manusia, edisi ke VIII, Penerbit Ghalia Indonesia, Jakarta .

Martoyo, Susilo, 2012 Manajemen Sumber Daya Manusia, Edisi Keempat, Penerbit BPFE, Yogyakarta

Muflichah, 2015.Tesis Unibraw Malang Pengaruh faktor-faktor motivasi terhadap produktivitas tenaga kerja operasional di lingkungan industri kecil Gresik.

Moekiyat, 2007, Manajemen Tenaga Kerja Dengan Hubungan Kerja, Pioner Jaya Bandung.

Nitisemito. Alex S, 2012, Manajemen Personalia, Edisi kedelapan, Ghalia Indonesia, Jakarta.

Nunnally, 1969.Using Mutivariate Statistics, third edition, Harper Collin. New York

Ranupandojo, Heidjrachman, 2014, Manajemen Personalia, edisi ke III, BPFE, Universitas Gajah Mada, Yogyakarta.

Robbin, Stepphen P, 2013.Orgnizational Behavior, Pretince Hall, New Jersey.

Siagian, Sondang P, 2013. Manajemen Sumber Daya Manusia, STIE YKPN, Yogyakarta.

Simamora, Henry, 2011, Manajemen Sumber Daya Manusia, STIE YKPN, Yogyakarta.

Singarimbun, Masri dan Effendi, Sofian, 2009, Metode Penelitian Survey, PT. Pustaka LP3ES, Jakarta.

Soeprianto, John, 2008, Manajemen Sumber daya Manusia, Karunika UT, Jakarta.

Sugiyono, 2012, Metode Penelitian Bisnis, CV.Alfabeta, Bandung.

Suharsono, Tesis Unibraw Malang. 2015. Pengaruh motivasi, kecakapan, kepribadian, peran dan kelelahan terhadap produktivitas karyawan di PT. Philips Ralin Surabaya

Sunyoto,2015. Tesis Unibraw Malang.Faktor-faktor motivasi terhadap produktivitas karyawan perusahaan rokok di Kotamadya / Kabupaten Malang. 